\title{
Editor's Note
}

\section{Denise L. Rode}

Every so often, a manuscript is submitted to The Journal of College Orientation and Transition that speaks to an editor personally and profoundly. Such was the case for me when I read the lead article in this edition, First-Year College Students' Homesickness and Separation Anxiety: Implications for Orientation, Retention, and Social Integration, written by Claborn and Kane. As a 17-year-old first-generation college student, I experienced the symptoms described in this article: feelings of stress, depression, isolation, and anxiety. In fact, I lasted all of five days at my first choice university, overwhelmed by a whirl of orientation activities which other new students seemed to be taking in stride. I encourage all orientation professionals to read Claborn and Kane's recommendations for integrating and retaining students like me, as nearly every campus serves new students who struggle with adult separation anxiety disorder and may be at risk for departure.

In this edition's second article, Gefen and Fish continue the focus on the challenges during transition to college by looking at gender differences in stress and coping in the first year. Those who work with first-year students will be interested to note differences in sources of stress and coping strategies between male and female students. Other significant student populations addressed in this JCOT issue include homeschooled students, orientation leaders, African American males, first-generation students, and doctoral students.

Practitioners will find plenty of food for thought in this issue. Several articles focus on the use of technology in orientation. Based on their successful S.T.R.I.P.E.S. camp at Louisiana State University, Ray and Korduner offer a Campus Notes piece with practical suggestions for developing extended orientation or "camp" models. Wilson and Varner report on a successful summer developmental program at Alcorn State University. Smith, Rodine, and Williams assess the effectiveness of an orientation program via learning outcomes based on Council for the Advancement of Standards guidelines.

Continuing professional development, including reading, is essential for NODA members. To that end, Savage contributes an insightful review of the book, The First-Generation Student Experience: Implications for Campus Practice, and Strategies for Improving Persistence and Success, by Jeff Davis. This edition closes with Miciek's Perspectives article about moving on with orientation training in the wake of an environmental crisis which affected her campus and community. I trust that you'll agree that this JCOT edition offers something for every reader.

Like students, scholarly journals go through transitions. This issue marks an editorial turning point for The Journal of College Orientation and Transition. Dr. Stephanie M. Foote, associate professor of education at Kennesaw State University in Georgia, assumes the position of JCOT Editor on March 15, 2012. Stephanie is eminently qualified for this role. She has served as an associate editor for this publication for the past year, has published and presented extensively, and was NODA's 2009 Outstanding Research award recipient. I trust that the National 
Orientation Directors Association will embrace and support her in this position as it has done during my seven years as Editor.

When I was that anxious 17-year-old college student experiencing separation anxiety, I couldn't have dreamed that I would one day find my career path in higher education, working with new and transitioning students. Nor could I have imagined one day editing a journal on orientation, transition, and retention for a respected association that has been my professional "home" for thirty years. I want to thank the leaders of the National Orientation Directors Association for entrusting me with the stewardship responsibility for this scholarly journal. This experience has been an unparalleled professional development opportunity and a source of many friendships and collegial relationships. It has made me a better practitioner and faculty member for both undergraduate and graduate students. I intend to continue my involvement with JCOT by actively contributing manuscripts, encouraging colleagues to contribute to the publication, and advancing our journal in every way possible.

I am proud of the progress we've made with The Journal of College Orientation and Transition in the past seven years. The Journal has nearly doubled in size, undergone a redesign, become more selective in accepting articles for publication, and has produced two special editions (one for NODA's 30th anniversary and another on academic advising). The quantity and quality of submissions have risen, and the research methodology employed in the research submitted has become more sophisticated and powerful. New sections-Pillars of the Profession featuring interviews with "the greats" of our field, and Perspectives, editorial pieces taking a stand on an issue or sharing a personal or professional experience related to the field-have been added. Increasingly, we see citations of JCOT articles in the scholarly literature. We are making our mark!

Perhaps the most significant JCOT development over the past seven years has been the establishment of the managing editor position; we could not have come this far without this essential staff role. Much of our progress is due to the tireless efforts of the two outstanding managing editors I've had the good fortune to work alongside-Sheena Williams (2005-2008) and Samvedna Dean (2009-2012). I have learned much from them, and the Journal is a stronger publication for their service. Our design and production partner Jeff Breaux (Main Campus Publications) in Nashville also has been a joy to work with throughout my tenure; Jeff has consistently delivered the finest quality product and service to us.

I have appreciated the collaboration of a fine group of associate editors over the past seven years, including Stephanie Foote, Wanda Hadley, David Johnson, Beth Lingren-Clark, Brenda McKenzie, David Rielley, Scott Silverman, Jeanine WardRoof, Dennis Wiese, and Greg Wolcott. My graduate assistants at Northern Illinois University-Ericka Loynes, Jennifer Riley, and Natasha McPartlin-have contributed countless hours proofing the JCOT. The NODA home office, under the able leadership of Executive Director Joyce Holl also has been a great source of support and encouragement, as has the NODA leadership, including Presidents Charlie Andrews, Craig Mack, and Cynthia Hernandez.

So it is with much gratitude and high hopes that I close my term as Editor of The Journal of College Orientation and Transition. Thank you for this opportunity to serve the Association. 